\title{
The Effects of Shortage and Abundance on Human Being in Ibn Khaldun Idealism
}

\author{
Aytekin Demircioglu \\ Sinop University, Faculty of Divinity, Sinop, 57000, Turkey \\ E-mail: demircioglu.aytekin@gmail.com
}

KEYWORDS Nutrition. Morality. Health. Islam. Muqaddimah. Climate. Food

\begin{abstract}
There has been a link between nutrition styles and human health and physical features for centuries. Similarly, there has been a connection between the easiness and difficulty to reach food materials, and shortage and abundance of these material and human behaviors and moral structure. One of the efforts to make a connection between these qualifications comes from Ibn Khaldun. A thinker of Islam, Ibn Khaldun, who lived in the $18^{\text {th }}$ century, stated that moral characteristics and physical features in the communities which are deprived of food materials are higher than those of the communities having a wealthy living. According to him, overeating leads to the accumulation of harmful wastes in the body and thus to the deterioration of both physical and mental health of human being. Therefore, eating abundant food materials might not result in positive results for man. In the current study, it was investigated how the opportunities of reaching abundant food and types of nutrition affected human health in general and moral structure in Ibn Khaldun.
\end{abstract}

\section{INTRODUCTION}

Ibn Khaldun was born on May $27^{\text {th }}, 1332$ in Tunisia. His original name was Abdurrahman, his personal record came from Abu Zayd and his title was Waliuddin. However, he was renowned with Ibn Khaldun depending on his family (coming from sons of Khaldun family) (Uludag 1993: 6-7). Ibn Khaldun introduced himself in his Muqaddimah, his famous work, as follows: "A servant needing for the mercy of Allah who has a lot of grace, Abdurrahman bin Mohammad bin Khaldun Hadhramy." (Ibn Khaldun 2009/I: I, 54).

The life of Ibn Khaldun could be divided into four periods (Uludag 2009: 15):

The first period is the time comprising the years between 1332 and 1351, which is from his birth up to twenty-one year old. Ibn Khaldun lived in Tunisia in this period. He memorized Koran and became a hafiz (the person memorizing Koran) in this period and studied religious sciences. He succeeded in the science of recitation.

The second period lasted about twenty-five years. In this period, which was between the years 1351 and 1375, he lived in such places as Tunisia, Algeria, Morocco and Andalusia and worked in a great many administrative and political services. In this period, he carried out the tasks of a clerk, an administrative consultant and a judge.

The third period comprises the years between 1375 and 1383. Ibn Khaldun lived the first four years of this period in the Castle of Ibn Salamah where he stayed away from political life and wrote Muqaddimah there. He spent the following four years in Tunisia.

The fourth period is the period comprising the Egyptian time when he lived between 1383 and 1406. In this period, he paid a spiritual visit to Mecca to become a pilgrim, and he worked in the services of kadi (judge) and mudarris (lecturer). During the siege of Damascus, the peacemaking he performed between the Tatar Sultan Timur and Egyptian Sultan Ferec was in this period (1400).

Ibn Khaldun has an autobiography and several books with religious content. However, the most famous is his Muqaddimah. Even though this masterpiece was written as a prologue to the work called Kitabu'l Iber starting as a world history, its fame exceeded the original book. Muqaddimah itself has six parts. The first book deals with the structure of earth surface, climate and the effects of it on human being. The second book deals with Bedouin - Hadari communities, presidency system, the concepts of state and nervousness. The third book is about the organization of state, the phases of establishment, development and collapse of a state, the tasks of caliph (the head of state in Caliphate) and sultan (a noble title). The fourth book contains issues with regard to countries, cities and civilizations. The fifth book deals with the 
ways of making a living, earnings and occupations. The last and sixth book contains sciences, the ways to learn sciences and the types of teaching and sciences.

\section{METHODOLOGY}

In the current study, the relation between the cases of shortage and abundance of food that appeared in the context of the effects of climate on human being and earth surface, which was mentioned in the first book of Muqaddimah by Ibn Khaldun, and the physical, mental and moral structure of human being, was investigated.

\section{The Relation between Human Being and Nutrition in Ibn Khaldun Idealism}

Ibn Khaldun divided the world into seven climatic zones. This division was made in a way to include lands more and from the south to the north in parallel with each other (Ibn Khaldun 2012/I: 1/II, 90-122). In this division, the fourth climatic zone in the center is the most suitable zone to live. The third zone to the central zone from the south and the fifth zone from the north are the second most suitable zones to live in. Other climatic zones lose their feature of being livable as you stay away from the center. Ibn Khaldun described the third, fourth and fifth zones as "temperate" zones. In this sense, first, second, sixth and seventh climatic zones are not temperate.

According to Ibn Khaldun (2012/I: 1/III, 123126), being a temperate zone or not has a direct effect on any kind of things related to human being. People living in the temperate zones are perfect in every aspect. These people have aesthetical values and live in nice and comfortable houses, wear nice clothes, their occupations and businesses are so developed and they are able to produce any kinds of tools and devices necessary for a good life. They also have a developed technology in mining. They can mine such materials as gold, silver, iron, copper and so on very easily. Trade and shopping are also improved in these zones. The countries within these zones are North African countries, Syria, Hejaz, Yemen, Iraq, India, Indus and China. People living in Andalusia and European countries like Italy and Greece, Welsh, Roumy (current Anatolia) and Greek people are also considered within these zones. However, the countries having the characteristics of being temperate the most are Syria and Iraq, since they are located in the center of these seven climatic zones.

Even though very few people live in the nontemperate zones, the negative features of climate could be seen on every feature of these people. Their skin colors are distorted, their physical features are weak and they have bad morality. They live far from civilization. Their houses are made up of mud and straws and their food is nothing but maize and plants. People living in these places do not know how to dress; therefore they cover their genital parts with the leaves of trees and furs of animals. Some of them avoid covering those parts and prefer living naked. They do not have a developed structure. They do not know to trade with gold and silver. They look like wild animals rather than human being and mostly live in caves. Some eat human flesh. As they are away from civilization, they are unaware of celestial religions. In the south, some of the Sudanese people having a very hot climate near equator and Eskimos and Slavs living in the seventh zone which has a very cold climate have these features (Ibn Khaldun 2012/I: 1/III, 123-126).

In Ibn Khaldun's idealism, hot climate does not only have an impact on the bodily characteristics of human beings but it also affects moral features and characters of the people living in these zones. Those living in the first and second climatic zones are generally hasty, wanton people indulge in fun and pleasure; they are poor in understanding and are indecisive. They generally do not have a concern for the future. On the contrary, people living in the highlands of Morocco are anxious and sad. They are not fond of entertainment so much and their concerns with regard to future are mostly pessimistic (Ibn Khaldun 2012/I: 1/IV, 127-128).

One of the basic criteria Ibn Khaldun used while saying that people living in poor conditions with regard food materials are superior in terms of moral virtues is: People who are accustomed to living in opulence could go in illegal ways in order to meet their needs, which are not so indispensable, obliged by luxurious living style they are in (Uygun 2008: 28). On the other hand, Bedouins are able to live with little food in a contended way. This status of satisfaction they have to go along with shows their moral features in a determinist way. If we are to formulate this case, luxurious life is a reason; moral corruption depending on that is a result (Kocak 2009: 52). 
Ibn Khaldun intensified his negative comments mostly on Sudanese and black people living in the first and second climatic zones which have a very hot weather. It is likely to say that he based on concrete observations in this issue, since he had some contacts with the people living in this region. Therefore, he comprised his ideas about the people living in this region depending on his personal observations and sometimes he expressed them by exaggerating. On the contrary, he had no concrete observations about the Slav and Eskimo people living in the regions near North Pole which he calls seventh climatic zone. That's why he did not have much comment on them. He only made an assumption for the sake of the internal consistency of his theory. According to this deduction, if hot weather makes a region unfavorable in terms of human life, cold weather should also lead to the same result. He combined these deductions with some other information compiled from some travelers and sailors and comprised his ideas about the people living in cold climates. Thus, he did not have very clear and strong information with regard to people living the places which he calls as the seventh zone.

In the next stage, Ibn Khaldun carried his theory of climate to issue of what kind of effects having poor or rich opportunities in terms of reaching food materials have on human being. According to him, in all of the countries in the middle climate zones having a temperate weather, the same abundance cannot be seen in reaching food materials. According to Ibn Khaldun (2012/ $\mathrm{I}: 1 / \mathrm{V}, 129)$, the most important factor for this is that the fertility of the land is not at the same level in these countries. Basic items of food such as grain, wheat and fruit are not grown in the places where soil is not fertile. Therefore, people living in these regions are in difficulty in obtaining their lively needs. Hejaz, the southern parts of Yemen and sandy places in the Maghreb Sahara are the examples for it. People of Hejaz, Yemenis, Murabits (Bedouins of western Egypt) and nomadic Arab people are deprived of the products grown in soil.

The most important food the people who are deprived of the products grown in soil is meat and milk. According to Ibn Khaldun (2009/I: 1/V, 129), these two items of food would replace wheat and grain in a perfect way. In other words, people having meat and milk do not need wheat and other products produced in soil. What's more, the physical health and moral characteristics of the people living in deserts and unfertile lands and having difficulty in reaching food items are far better than those living in fertile lands and having an ability to reach food items easily for Ibn Khaldun.

These people living in the deserts and unfertile lands as mentioned by Ibn Khaldun are called "Bedouins" due to their life styles. The contrast for Bedouins is known as "Hadari". Hadari communities mostly live as located on a certain land and have more facilities (Toku 2002: 92). According to Ibn Khaldun, being a Bedouin is not a preference for a lifestyle but only a compulsion. Therefore, Bedouin communities evolve into Hadari communities in time (Uludag 1993: 6570). The basic motivating force of this evolution is the financial activities caused by needs (Kozak 1999: 24-26). In other words, from Ibn Khaldun's perspective, the characteristics that make Bedouin communities innocent in the sense of humanism, high in morality and strong physically result from their primitive way of life which they try hard to get rid of it paradoxically.

Ibn Khaldun put forward some physical and concrete ideas about how the abundance of food materials harmed human being. According to him (2012/I: 1/V, 129-132), the abundance and moisture in food materials bring about the formations of some harmful accumulations and wastes in the body. Body becomes enlarged and deformed due to these wastes in a disproportionate way. Some deformations appear in the inner organs and body secretes bad excretion. It is followed by the skin's turning into a dull and pale color. In that way, people getting fatter and fatter would have a bad body in terms of both appearance and health. The moisture produced exceedingly due to overeating goes up to the brain and prevents it to work properly, so people eating too much have such cases as diverting from what are normal, inattention, carelessness, stupidity and mental retardation.

Ibn Khaldun classified people and communities into three in terms of food and nutrition facilities (Ibn Khaldun 2012/I: 1/V, 129-132; Uludag 2009: 270, 10. Footnote):

First: People living in moorlands, arid and unfertile lands

Second: People living in fertile lowlands and plains, in the soils where a lot of food is harvested.

Third: People living towns and cities. 
The first group has to work hard and put an effort to obtain food in little amounts. This continual case of struggling keeps them active and strong. Their skin colors are brighter, bodies are shaped and characters are in the medium state. In addition, their capacity of perception is high and mental skills are improved. Those in the second group do not have to work harder in order to obtain food due to the fact that the land they live on is fertile. It causes the accumulation of harmful materials in the body so leading to impairment of health. Their skin colors are paled, bodies are fat and ugly. Their mental perception is less. The third group is just like the second group in reaching food materials. However, the people living in the towns and cities process their food before consuming like cooking, salinization, drying and pickling. These processes lessen the negative effects of foods. The process of refining and lightening in food is reflected in the bodies of urban people consuming them. Therefore people living in cities (Hadaris) have more delicate bodies and softer tempers compared to those living in deserts (Bedouins). However, Ibn Khaldun considers it as an indication of deformation rather than a positive feature.

Ibn Khaldun did not only make a comparison between humans over the case of abundance and shortage in obtaining food. According to $\operatorname{him}(2012 / \mathrm{I}: 1 / \mathrm{V}, 129-132)$, there are some differences between animal fed with abundant and excess food and animals fed with less food. Such animals as gazelle, ostrich, wild goat, giraffe, wild donkey and cattle rose in deserts and arid regions are different from those raised in the pastures with abundant water, grass and plants in favor of the first group. The skins of these animals are smooth and bright, the bodies are shapely, their organs are consistent and their perceptions and feelings are stronger. According to Ibn Khaldun (2012/I: 1/V, 131-132), the reason for this is that some wastes, bad materials and harmful excretions accumulate in the bodies of the animal fed with abundant food in the highlands, just like the bodies of humans consuming a great amount of food. And these have negative effects on the body structures, skin colors and general health conditions of animals. On the other, hunger and shortage beautify the bodies of animals in the arid areas as much as possible.

Ibn Khaldun made a comparison between those living in shortage and abundance in terms of their religious lives and ways of praying. Ac- cording to him (2012/I: 1/V, 129-132), those living in deserts and exposed to shortage and those having limited opportunities due to financial difficulty even though they live in cities have a better religious life compared to the ones living in abundance and wealth. These people are more indulgent in praying. According to Ibn Khaldun, since people living in cities consume more fine wheat flour, oil and meat, their hearts become hardened and stay away from praying. Therefore, the numbers of religious people are fewer in cities and towns.

According to Ibn Khaldun (2012/I: 1/V, 131132) people who are accustomed to living in abundance lose their ability to resist against troubles. These people would be defeated very easily in the case of experiencing shortage and hunger years. Ibn Khaldun expressed that Barbary people in Maghreb, people of the city of Fas and Egyptian people have such kind of weaknesses. On the other hand, Arab living in the desert and whose main food is date Andalusian people whose main food was maize and olive and the people of Ifriqiya (the region of current Tunisia, western Libya and eastern Algeria) making their living mostly out of barley and olive did not have great collapses. Since they were accustomed to shortages in their daily lives, their resistance did not fall in general shortage times.

Ibn Khaldun tried to explain the case of the people falling into shortage from abundance and being affected by it with some medical explanations. According to him (2012/I: 1/V, 129-132), people living in abundance adapt this condition so easily since they consume animal fats, inner organs and intestines, and foods and oils so much. And it leads to more moisture in the organs than what it should be. When humans whose organism are shaped depending on their position fall in shortage and hunger suddenly, it might be destructive for them, since their organs are accustomed to weakness and delicacy. In the case of a hunger, the intestines of these people become dry, wrinkled and lose their function. For that reason, the death toll in these periods is high. However, what kills people in these times is not the emerging hunger position depending on the shortage. The main factor that kills them is the case of fullness which is present beforehand and strong habit in terms of body.

According to Ibn Khaldun (2012/I: 1/V, 131132), people leaving the habit of eating solid food ingredients and butter and consume milk as the 
basic food material are healthier, since the moisture and water balance in their bodies could stay without any impairment. Since the moisture in body is consistent with all of the natural food materials, there will be no impairment in the case of a change of foods in the intestines of those consuming milk as a natural material of food. Therefore, medical problems that occur due to the abundance of foods do not happen in these people.

It is likely to infer this result from the explanations of Ibn Khaldun implicitly. According to him, milk, meat and the products growing in soil naturally are in the group of natural products. On the other hand, such products as wheat that are obtained through the cultivation of soil are not regarded as natural products. In addition, butter that is obtained through a process is not regarded as a natural product. Upon the evaluation of current criteria, it true to say that Ibn Khaldun is very selective in terms of natural products and does not have a large scale of products.

According to Ibn Khaldun, there is only one reason why people consume food materials more than necessary. It is nothing but habit. People living abundance and being able to obtain foods easily get accustomed to eating much. This habit leads to the accumulation of harmful materials and to the impairment of both their health and their morality. The reason why rich people falling into shortage are affected by such a case is the same. As their body is accustomed to consuming foods much, it is not easy for them to adapt to the new case and some will die since they cannot adapt to this case. However, according to Ibn Khaldun, man can be accustomed to shortage just as he is accustomed to abundance. What should be done is to lessen food intake to body gradually. After this habit is realized, man will be healthy both physically and mentally. Ibn Khaldun completed the discussion by expressing that it was proved by experience and some close friends observed it personally.

\section{CONCLUSION}

Ibn Khaldun regards people's being in a shortage or abundance in terms of reaching food materials as a physical reality. People living in deserts and arid places are really deprived of reaching foods grown in soil. On the other hand, those living in well-watered and fertile lands and the ones living in cities due to their power to buy items live in abundance in terms of food materials. In that way, the effects of living in abundance or shortage on human being were taken in a practical and real plane depending on factual observations by Ibn Khaldun rather than theoretical plane.

Ibn Khaldun evaluated the case of shortage and abundance in terms of their effects and results on human being. In this sense, a situation of shortage encountered as a way of lifestyle is indeed a positive thing with its general and long term results, since it requires a continual struggle. In addition, as overeating causes harmful accumulation in the body, it makes man fat and unhealthy. At the same time, the water and moisture balance is lost with overeating and intestines, inner organs and brain cannot work efficiently.

According to Ibn Khaldun, man should not eat less only in the situations where there is no chance to reach abundant food. Those having more facility to reach food, in particular the ones living in cities should get accustomed to live on little food by being aware of the harmful outcomes of overeating. In that way, the true thing to be done is to adopt a habit of nutrition with less and less food.

The harms of overeating are known to modern man. As a matter of fact, the fact that some countries consider obesity one of the most important problems is one of the most significant indications how Ibn Khaldun's ideas which he mentioned sixteen centuries ago in this issue are so valuable. Consuming food materials more than necessary does not only harm human body individually, but it also causes a great many social and political problems. While some people in the world spend a large sum of money to get rid of their weights, some other people die of hunger in some other parts of the world. This injustice between groups is one of the important problems that human being must solve. In this context, the views of Ibn Khaldun must be taken into consideration and Ibn Khaldun must be reconsidered with current concepts and problems.

From this point of view, it true how Ibn Khaldun theory is value. However, its being valuable does not mean there is nothing to criticize this theory. Even though agreeing upon the view that over eating could lead to health problems, the researcher believes that the following issues could be criticized.

First of all, the information and the explanations Ibn Khaldun gives are exaggerated. As an 
example, the fact that some people live on consuming only milk and that they live long is just an exaggeration.

Second one is that regarding such products as milk, meat, olive and maize healthy but wheat as unhealthy is not consistent with the scientific facts of the modern time.

Third one is that there are not so many reasons for Ibn Khaldun to experience the case of shortage actively and for a long time since he spent most of his life working in state work with higher titles. In fact, he has no explanation in this sense. In addition, he made his explanations not basing upon his own life, but on his observations.

Fourth one is Ibn Khaldun stated that people living in abundance do not only have bad health, but their intelligence and capacity of perception is also low. He also expressed that those living in abundance are the people living in well-watered and fertile lands and the ones living in cities. However, it was told in the eight part of the sixth book of Muqaddimah that science could only studied in cities. Even though these two issues were expressed independently in different contexts, there is a contradiction between the two.

Fifth one is that overeating increases moisture in the body and it goes up by evaporation and has a negative impact on the working of both brain and other organs. It should be indicated that these explanations have nothing to do with the medical facts of the current time.

Even though such kind of criticism could be made upon his views, it is true that these views are the theories that exceed the knowledge and understanding level of his age in terms of the historical process and the realities of geography and community he lived.

\section{REFERENCES}

Ibn Haldun 2009. Mukaddime. $6^{\text {th }}$ Edition. Prepared by Suleyman Uludag. Istanbul: Dergah Publishing.

Ibn Khaldun 2012. The Muqaddimah: An Introduction to History. Translator: Franz Rosenthal. 3 Volumes. $1^{\text {st }}$ Edition 1958. London: Routledge - Kegan Poul. From <http://asadullahali.files.wordpress.com/ 2012/10/ibn_khaldun-al_muqaddimah.pdf > (Retrieved on 16 December 2013).

Kocak M 2009. Ibn Haldun: Hayati ve Eserleri Uzerine Dusunceler. Ankara: The Publishing of Alternatif Politikalar Merkezi.

Kozak IE 1999. Insan - Toplum -Iktisat:Ibn Haldun'dan Yola Cikilarak Cok Yonlu Bir Tahlil Denemesi. Adapazari: Degisim Publishing.

Toku N 2002. Ilm-i Umran:Ibn Haldun'da Toplum Bilimsel Dusunce. Ankara: Akcag Publishing.

Uludag S 1993. Ibn Haldun: Hayati - Fikirleri - Eserleri. Ankara: Turkiye Diyanet Vakfi Publishing.

Uludag S 2009. “Giris” (In Muqaddimah). Istanbul: Dergâh Publishing.

Uygun O 2008. Ibn Haldun'un Toplum ve Devlet Kurami. Istanbul: On Iki Levha Publishing. 